\title{
The Mediating Role of Early Maladaptive Schemas in the Relation between Personality and Hardines
}

\author{
Marzieh Sadat Ebrahimi ${ }^{1}$, Nemat Tavvosi ${ }^{2 *}$ \\ 1- Master of General Psychology \\ 2- Assistant Professor, Faculty of Psychology and Educational Sciences, Tehran South \\ Branch (Corrsponding Author)
}

\begin{abstract}
Objective: The purpose of this study was to determine the mediating role of the uncompromising initial schemas in the relationship between personality and hardiness.

Method: The present study was a descriptive-correlational study. The statistical population included students from Payame Noor University of Qom. Based on the first stage sampling, the Faculty of Psychology was selected randomly and 550 persons were available as an example to the Big Five Factor Personality Inventory (Costa \& McQuery, 1985), Early Maladaptive Schema Questionnaire (Yang, 1990) and, Personal Views Survey (PVS; Institute of Hardness, 1985) responded.

Results: Path analysis showed that the research model had a good fit and $23 \%$ of the variance in the schema of separation and exclusion was explained through the neuroticism, extroversion, openness to experience, consensus, and taskability. Also, these veins and the separation and rejection schema had the ability to explain 30 percent of the toughness variance.

Conclusion: The initialized schemas have a mediatorial role in relation to personality traits and hardiness. Regarding the findings, it can be argued that the personality tracks and the initialized schemas play an important role in predicting student hardiness.
\end{abstract}

Key words: five-factor personality traits, hardiness, separation and exclusion schemes 


\title{
نقش واسطهاى طر حوار ههاى سازش نايافته اوليه در رابطه بين شخصيت با سر سختى
}

\author{
مرضيه سادات ابر اهيمى ؛ د دكتر محترم نعمت طاوسى \\ 1- كارشناسى ارشد روانشناسى عمومى ميحرم \\ 2- استاديار، دانشكده روانشناسى و علوم تربيتى واحد تهران جنوب (مولف مسئول)
}

جكيله

هدف: هدف اين يزوهش تعيين نقش واسطهاى طرحوارههاى سازش نايافته اوليه در رابطه بين شخصيت با سرسختى بود.

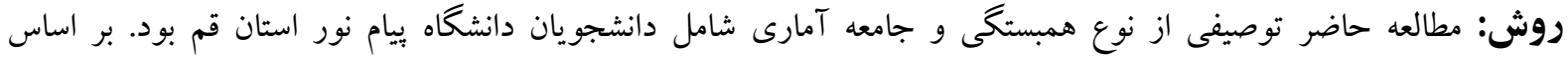

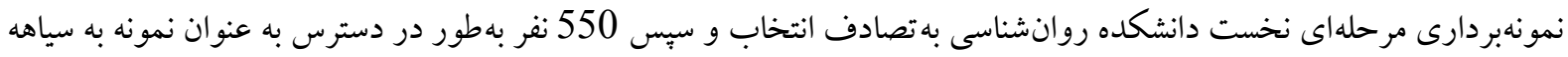

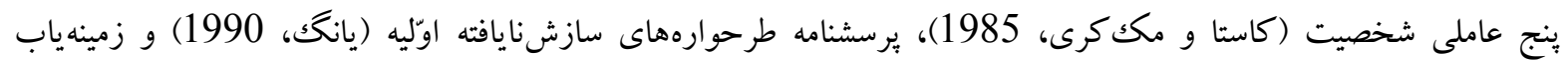

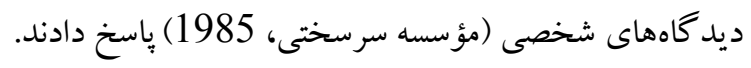

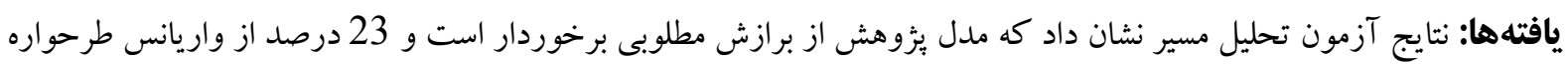

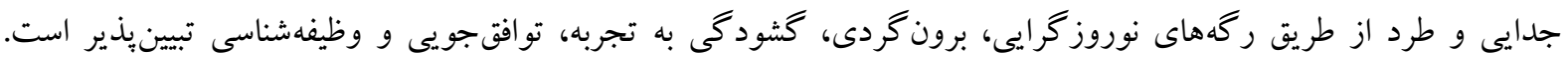

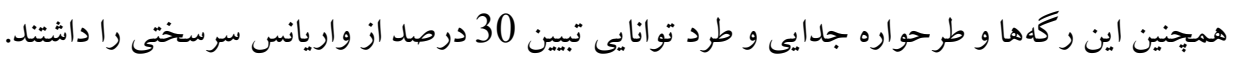

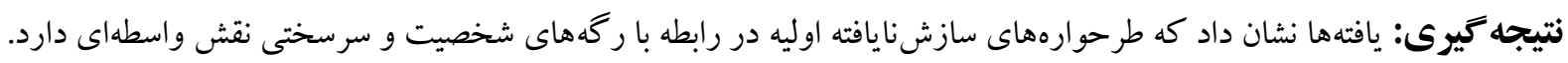

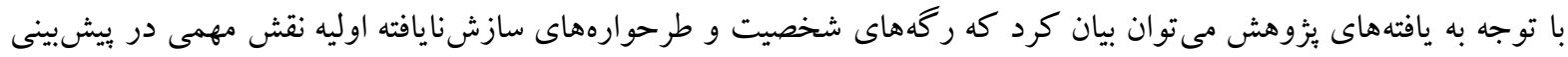
سرسختى دانشجويان دارند. كليد وازهها: رگههاى ينج عاملى شخصيت، سرسختى، طر طر حواره جدايى و طرد 


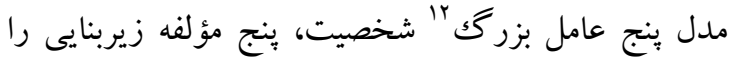

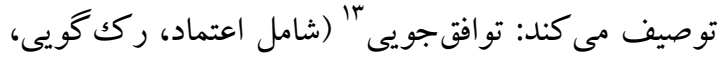

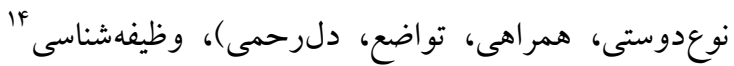
(شامل كفايت، نظم، تلاش براى موفقيت، خويشتندارى،

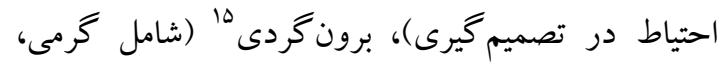

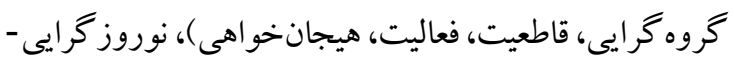

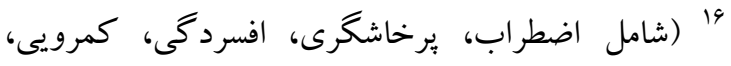

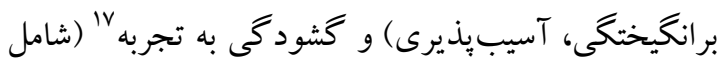
تخيل، زيبايىشناسى، احساسات، اعمال، عقايد و ارزشها)

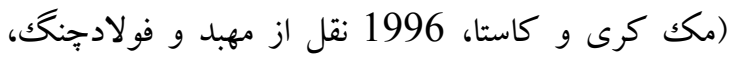

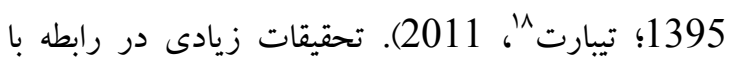
ركه هاى شخصيت با سرسختى انجام شده است. مكك كان،

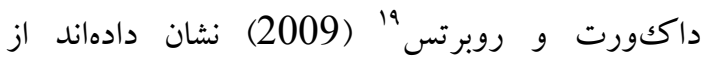
ويزگ گهاى مهم افراد وظيفهشناس سرسختى است.

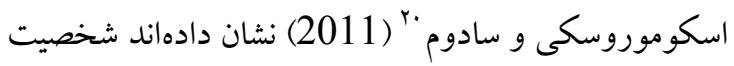
و سرسختى بر سلامت روانى و بهزيستى تاثير مى گذارند. يزوهشها نشان مىدهد افراد سرسخت از سطوح بالاى لئى

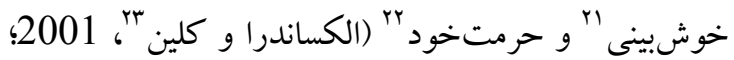

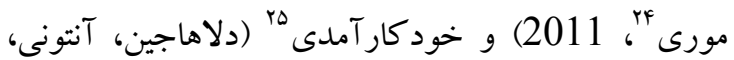

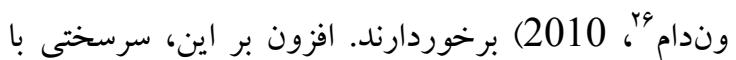
هيجانهاى منفى از جمله غمخينى، اضطراب و احساس

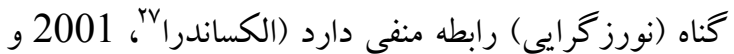

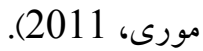

اين نكته نيز آشكارشده است كه شخصيت با بال

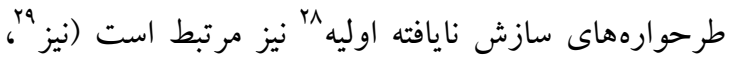

12- Five Factor Model (FFM)

13- agreeablenes

14- conscientiousness

15- extraversion

16- neuroticism

17- openness to experience

18- Tibaret, D. H.

19- MacCann, C., Duckworth, A. L,. \& Roberts, R. D.

20- Skomorovsky, A., \& Sudom, K.A.

21- sanguineness

22- self-esteem

23- Alexander, D. A., \& Klein, S.

24- Murray, R.A.

25- high efficacy

26- Delahaij, R.G., Anthony, W.K., \& Van Dam, K.

27- Alexander, D. A

28- early maladaptive schemas

29- Jens C, T.
مقدمه

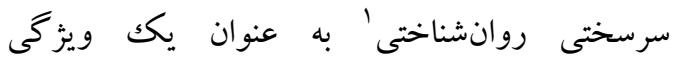

شخصيتى مقاومساز در مقابله با فشارهاى روانى، امروزه مورد توجه قرار گرفته است (شرد و كلباى'، 2007). كوباسا، مدى و كان' (1982) سرسختى را ويزگ شخصيتى بيجِيدهاى معرفى مى كنند كه از سه مؤلفه مبارزه جويى "، مهاره" و تعهد " تشكيل شده است. فردى با سطوح بالاى مبارزهجويى، رويدادهاى زندگى را به منزله فرصتى براى يويايى و ساز كارى مجدد و ميدانى براى يزّوهش و ارتقاى خويشتن تلقى مى كند و در برابر اين رويدادها به طور منفعل تسليم نمىشود. در مقابل افراد با سطوح يايين مبارزه جويى در برخورد با حوادث به جالش كشيده مى شوند. در اين افراد مبارزهجويى در سطح يايينى قرار دارد

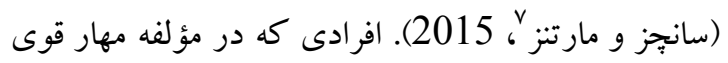
هستند، رويدادهاى زندكى را قابل ييشبينى و مهار مىدانند و بر اين باورند كه قادرند با تلاش آنجه را كه در اطرافشان رخ مىدهد تحت تأثير قرار دهند. عملكرد افراد با مهار كامل دارند نشان مىدهد كه آنها با رويدادهاى تنيدگىزا برخورد مى كنند و در مسئوليتهاى خود براى زندگى اصرار دارند و قادرند به طور مستقل عمل كنند (ترايمرادى، 2014). افرد با سطوح بالاى تعهد، نه تنها خود را واجد ارزش مىدانند بلكه رويدادهايى را كه اهميت و معناى زيستن را براى وى برجسته مىسازند، ارزشمند مى دانند (كوباسا، 1979؛ مدى، 2013). شواهد

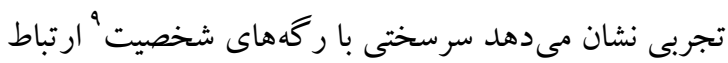

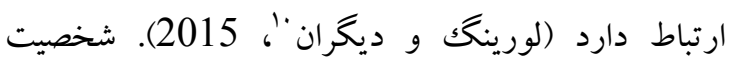
ركههاى نسبتاً پايدار است كه باعث مىشود افراد به شيوههاى خاصى رفتار كنند (كوركك"، 2015). نظريه

\footnotetext{
1- psychological hardness

2- Sheard, M. \& Golby, J.

3- Kobasa, S.C., Maddi, S. R. \& Kahn, S.

4- challenge

5- control

6- commitment

7- Sanchez, F., \& Martnez, H.

8- Tarimoradi, A.

9- personality tracks

10- Lovering, M. E., Heaton, K. J., Banderet, L. E., Neises, K.,

Andrews, J. \& Cohen, B. S.

11- Quirk, S. E.
} 
مىتوان اشاره كرد (اوريو، كالويت و يّاديلا، 1914 2014). برون گردى نيز با اكثر طرحوارهها رابطه منفى دارد (امانى،

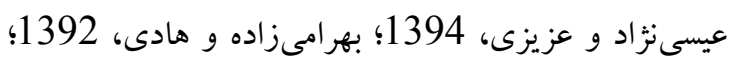

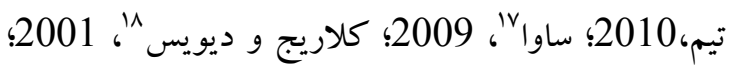

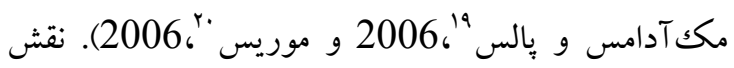

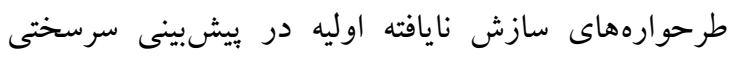

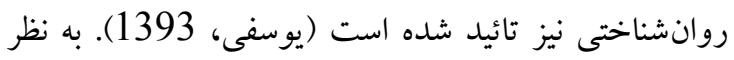

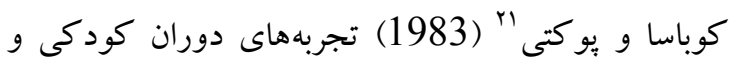
تعامل با والدين و اطرافيان مىتواند منجر به يكك شخصيت

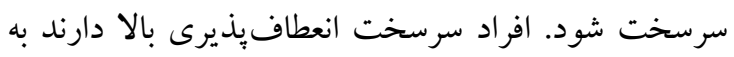
جاى اتكا برجنبهاى ثابت زندگى بر انجام تغييرات و و تطابق با شرايط تمركز دارند. در اين راستا تحقيقات نشان

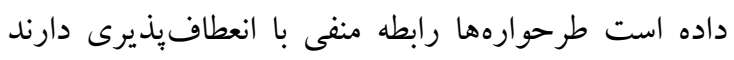

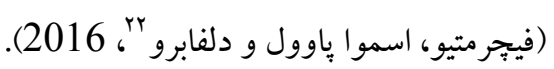

با توجه به اين كه بيشينهاى موجود در اين حوزه نشان

مىدهد كه رگكهاى شخصيت با طرحوارهها (بتماز،

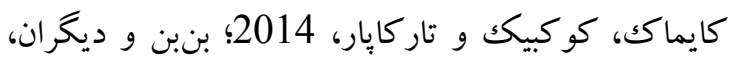

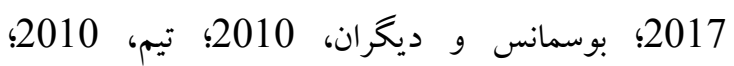

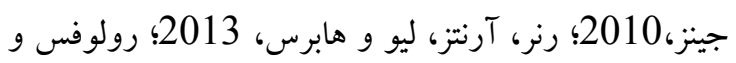

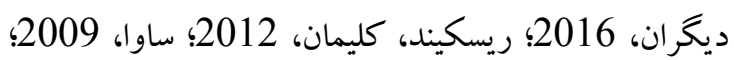
فلينك و ديخران، 2017؛ كالويت، 2014؛ كارتر و و ديخران، 2013؛ لهى، 2012 و مالو گيانيز و ديخران،

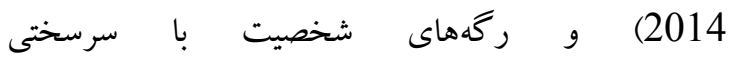
(اسكومورووسكى و سادوم، 2011؛ تئيدور و ديخران،

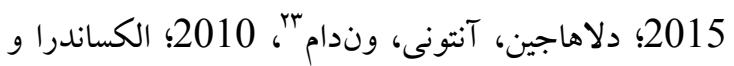

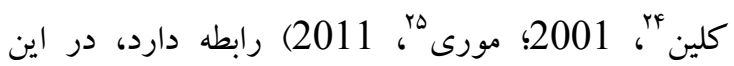
يزٔوهش مدل زير (شكل 1) تدوين شد تا مشخص شود آيا

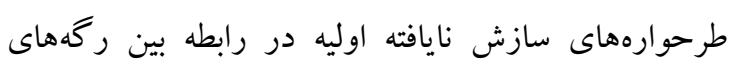

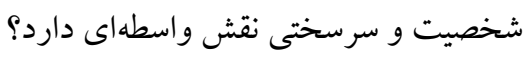

16- Orue, I., Calvete, E. \&. Padilla, P.

17- Sava, F. A.

18- Claridge, G., \& Davis, C.

19- McAdams, D.P., \& Pals, JL.

20- Muris, P.

21- Kobasa, S.C., \& Puccetti, M.C.

22- Fischer, D., Matthew, F., Smout Paul, F. \& Delfabbro, H.

23- Delahaij, R.G., Anthony, W.K,. \& Van Dam, K.

24- Alexander,D.A., \& Klein, S.

25- Murray, R.A.
2010). خلقوخوى هيجانى كودكى در تعامل با وقايع دردناك دوران كودكى منجر به شكل گيرى طرحوارهها

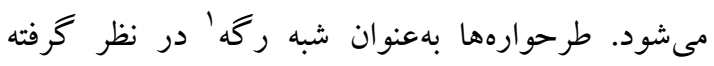

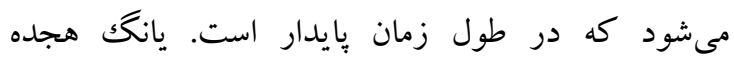

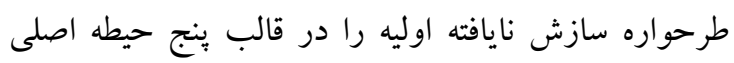
طبقهبندى كرده است: حيطه طرد و جدايى با، حيطه استقلال

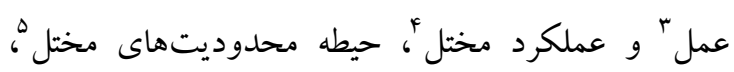

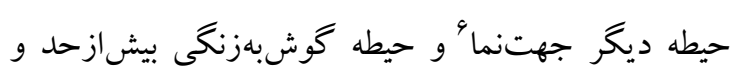

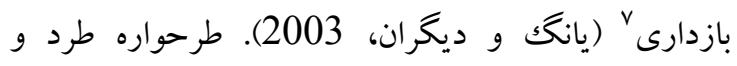

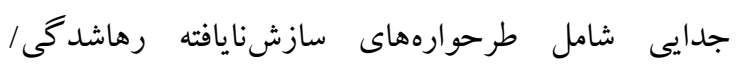

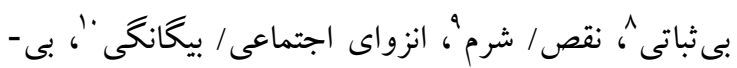

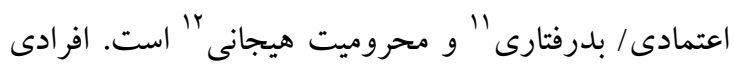

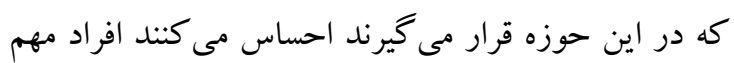
زندگىشان نمى تواند حمايت عاطفى و تشويق لازم را به آنه

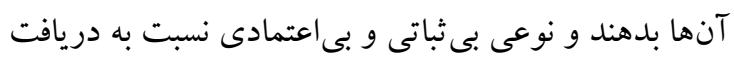

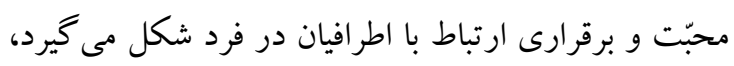
در نتيجه احساس نقص، حساسيت به انتقاد، سرزنش و نياز به اثبات خويش، امنيت و همدلى از مشخصههاى بارز

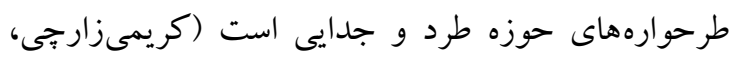

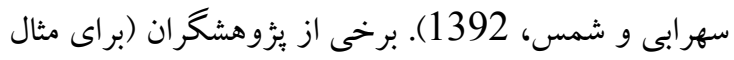

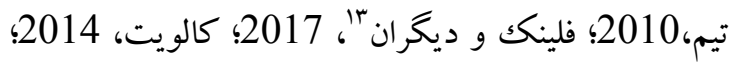

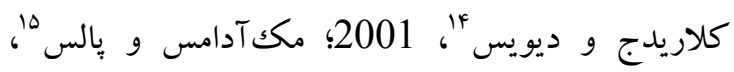

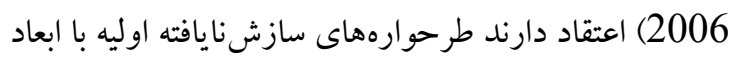
شخصيتى رابطه دارد و بنابر اين امكان يكيارجّلى و تر كيب

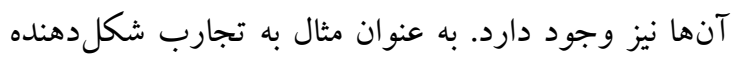

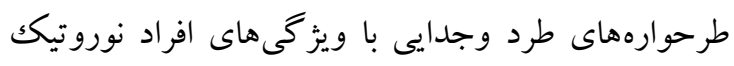

\footnotetext{
1- trait-like

2- rejection and disconnection

3- impaired autonomy

4- impaired autonomy and performance

5- impaired limits

6- other - directedness

7- overvigilance / inhibition

8 -abandonment / instability

9 -defectiveness / shame

10- social Isolation / alienation

11- mistrust/abuse

12 - emotional deprivation

13- Flink, N., Lehto, S. M., Koivumaa-Honkanen, H.,

Viinamäki, H. Ruusunen, A., Valkonen- M. \& Korhonen,

Honkalampi. K.

14- Claridge, G., \& Davis, C

15- Mc Adams, D.P., \& Pals, J.L.
} 


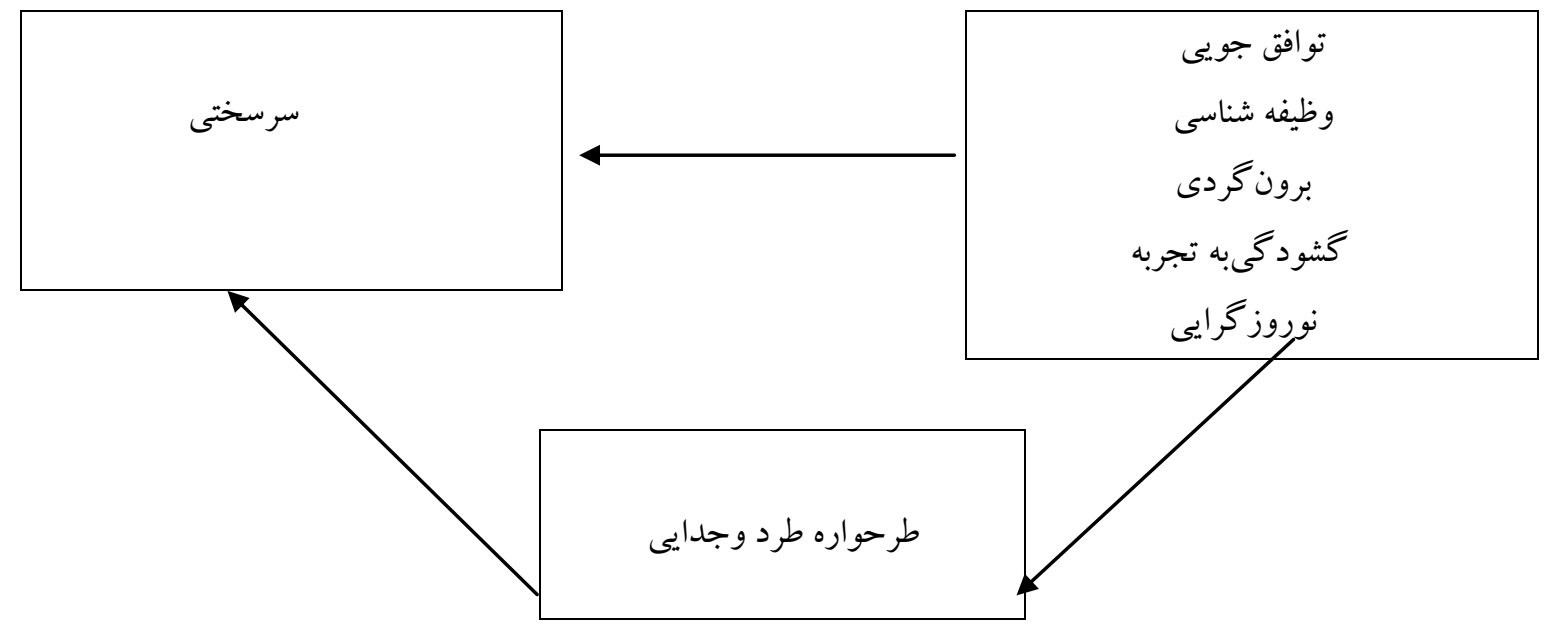

16، 21، 26، 31، 36، 41، 46، 51)، برون گردى

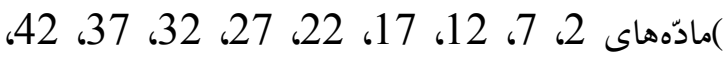
47، 52، 57) گشودگى به تجربه (مادّهاى 3، 8، 13، 18، 23، 28، 33، 38، 43، 48، 53، 58،

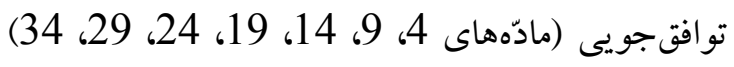

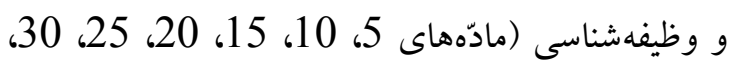
35، 40، 45، 50، 55، 60) را اندازه مى گيرد. ياسخدهى به اين ركهها در قالب ليكرتى ه درجهاى (كاملاً مخالف، بى تفاوت، نظرى ندارم، موافق، كاملاً موافق) امكانيذير است (فرخنيا و سليمانى، 1393). نمره كذارى فرم كوتاه اين سياهه در تمام مادهها يكسان اندان نيست. به اين معنى كه در نمره كذارى برخى از ماده - نداه

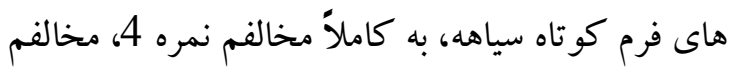
نمره 3، بى تفاوت نمره 2، موافقم نمره 1 و كاملاً

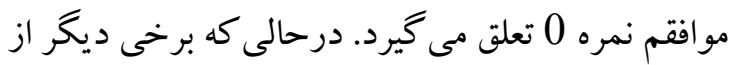

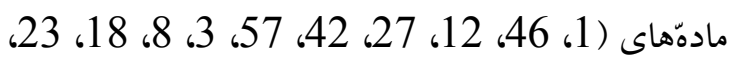
33، 38، 48، 98، 14، 24، 29، 39، 44، 54، 15، 30، 45 و 55) اين فرم كوتاه به صورت معكوس نمره كذارى مىشوند (كروسى فرشى، ركة ينج عاملى شخصيت توسط مك كرى ونى و كاستا (1983 نقل از فرشى، مهريار و طباطبايى، 1380) روى 208 نفر از دانشجويان آمريكايى به فاصله سه ماه
اين يزوهش توصيفى و از نوع همبستى است.

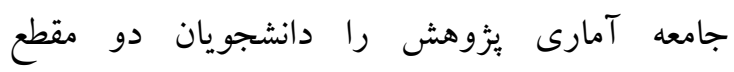
كارشناسى و كارشناسى ارشد دانشكاه بيام نور استان قم در سال تحصيلى 96- 95 تشكيل داد. بر اساس كاس نداس روش نمونهبردارى مرحلهاى نخست دانشكده روانشناسى به تصادف انتخاب و سبس 550 نفر به طور در

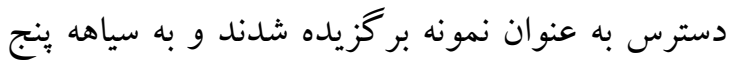

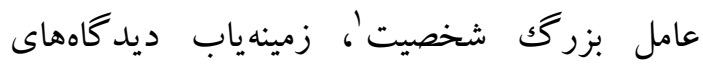

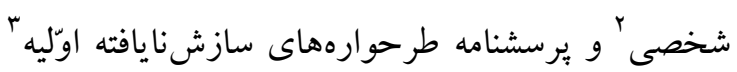

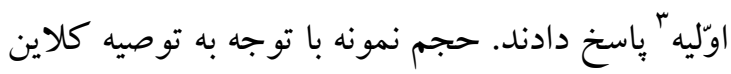
كلاين (2011) مبنى بر آنكه به ازاى هرماده 2/5 تا 5 نفر كفايت مى كند، تعيين شد. 30 بإخخنامه به دليل

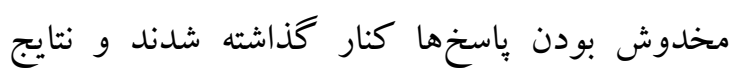

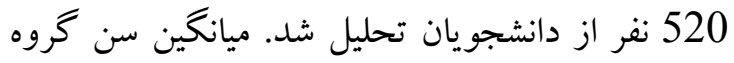

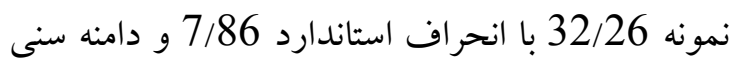
آنها 23 تا 55 سال بود.

\section{سياهه بنج عامل بزركى شخصيت (كاستا و} مكك كرى، 1985). فرم كوتاه اين سياهه شامل 60 ماده است. اين سياهه 5 ر رٔه نوروز كرايى (6، 1، 11، 11،

1- Big Five Factor Personality Inventory

2- Personal Views Survey (PVS)

3- Early Maladaptive Schema Questionnaire 
به كمك مقياس درجهبندى شش گزينهاى نمره كذارى

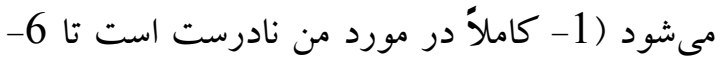
كاملاً در مورد من درست است). نمرههاى اين يرسشنامه با جمع نمرههاى مادههاى هر زيرمقياس به

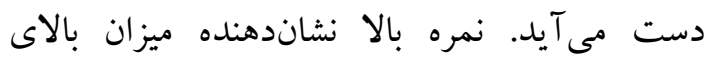
طرحوارههاى سازشنايافته اوّليه در آزمودنى است (منجم، آقا يوسفى و زارع، 1392). اعتبار اين يرسشنامه را به روش همسانى درونى و باز آزمايى بر روى يكك نمونه 564 نفرى از دانشجويان آمريكايى به ترتيب 0/95 و 0/81 گزارش شد (يانگك، نورمن' وتوماس'، 1995 نقل از يوسفى، اعتمادى، فاتحىزاده،

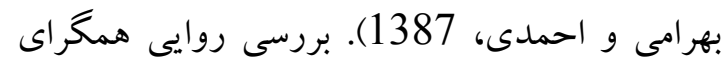

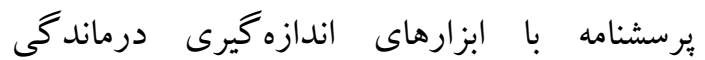

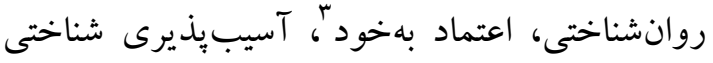
براى نشانگان اختلال افسردگى و علائم اختلال شخصيت نشان داد كه طرحوارههاى سازشنايافته اوّليه ارتباط منفى با ويز گىهاى مثبت مانند اعتماد بهخود، عاطفه مثبت و ارتباط مثبت با اختلال شخصيت،

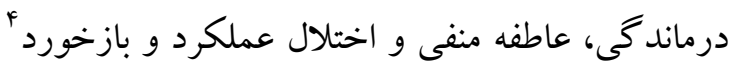
داشتند (يانگك و براون، 1994). همجِينين در ايران يوسفى و ديخران (1387) روايى و اعتبار برسشنامه طرحوارههاى سازشنايافته اوّليه را بر روى يكك نمونه 579 نفرى در دو مرحله (مرحله اول 394 نفر و مرحله دوم 185 نفر) بررسى و اعتبار آن را به روش آلفاى كرونباخ و دو نيمه كردن در كل نمونه به ترتيب 0/91

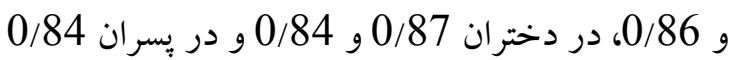
و 0/81 گزارش كردند. يوسفى و ديخران (1387) آلفاى كرونباخ مربوط به عامل انزواى اجتماعى/ بيگانگى ه 0/91 و عامل خويشتندارى ناكافى/ خود برد

1- Norman, S.

2- Thomas, J.

3- sehf confidence

4- attitude

5- social isolation / alienation
اجرا شد كه ضرايب اعتبار به ترتيب براى نوروز گرايى 0/83، برون گردى 0/75، گشود گیى به تجربه 0/80، توافقجويى 0/79 و وظيفهشناسى 0/V9 بهدست آمده است (فرشى، مهريار و طباطبايى، 1380). يك مطالعه

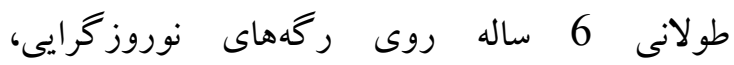
برونگردى و گشودگى به تجربه، ضريبهاى اعتبار 0/68 تا 0/83 را در گزارش هاى شخصى و نيز در كزارشهاى زوجها نشان داده است. ضريب اعتبار دو عامل توافقجويى و وظيفهشناسى به فاصله دو سال به ترتيب 0/79 و 0/63 بوده است (مككرى و كاستا، 1983 نقل از گروسى فرشى، 1380). همجينين كاستا و مكك كرى (1999) روايى اين ابزار،

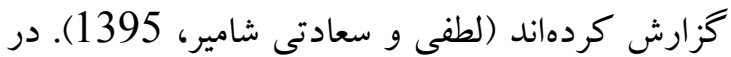
مطالعه گروسىفرشى (1377) ضريب همسانىدرونى كل اين سياهه در حدود0/70 و ضروايب رتبى آلفاى

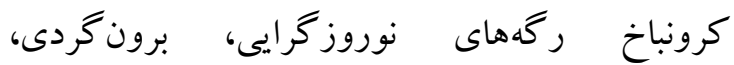

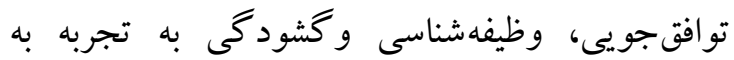

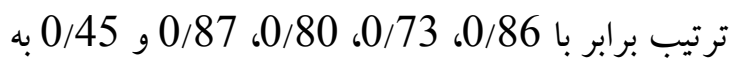
دست آمد. كيامهر (1381) نيز اين سياهه را بر روى برى دانشجويان ترجمه و اجرا كرد، روايى همزمان بين فرم كوتاه و بلند اين سياهه را براى ينج عامل بين 0/41 تا تران

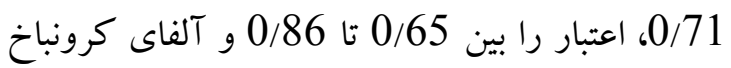
زيرمقياسها را بين 0/54 تا 0/79 گزارش كرده است. ين. در يزوهش حاضر ضريب آلفاى كرونباخ براى ركههاى شخصيت به صورت كلى 0/714 به دست آمده

\section{يرسنامه طرحوارههاى سازش نايافته اوّليه (-} EMSS 90 ماده است كه 18 طرحوارههاى سازش رادر بنج حيطه اندازه مى گيرد. اين برسشنامه را براى گروه سنى

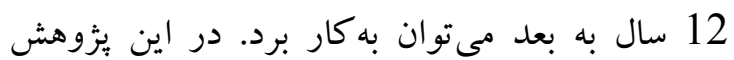

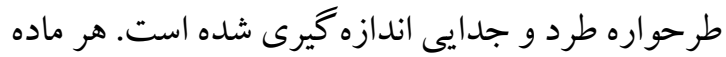


1998، اوئلت؛؛ 1992 نقل از مدى و هاروى؛

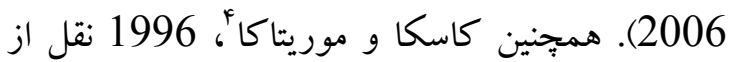
تيمورى، 1383) ضرايب اعتبار مؤلفههاى سرسختى (تعهد، مهار و مبارزه جويى) را به ترتيب برابر با 0/70،

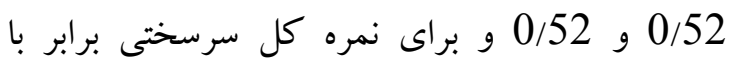
0/75 به دست آوردند. بررسىهايى كه در ايران براى تعيين ويز گیىهاى روانسنجى زمينهياب ديد گاههاى

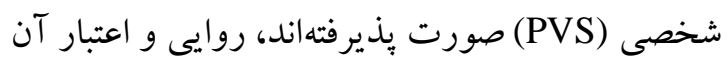

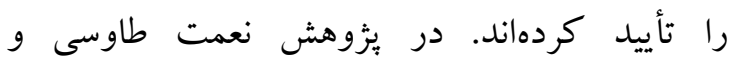
محمدعلىشريفى (1388) نيز مقادير ضريب آلفاى كرونباخ برابر با 0/85 مؤيد اعتبار قابل قبول اين ابزار بود. همجنين حقيقى، عطارى، رحيمى و سليمانىنيا، (1378) ضريب آلفاى كرونباخ را براى زمينهياب سرسختى و عاملهاى تعهد، مهار و مبارزهجويى به

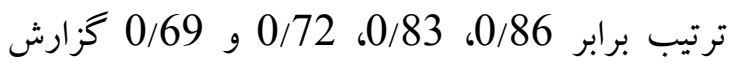
كردهاند (ايوبى، تيمورى و نيرى، 1389). در بزّوهش حاضر ضريب آلفاى كرونباخ براى سرسختى 0/880 به دست آمده كه نشان دهنده اعتبار بالاى اين ابزار است. براى تحليل داده ها از آزمون همبستخى و تحليل مسير استفاده شد.

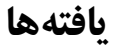

براى بررسى رابطه بين طرحواره جدايى و طرد،

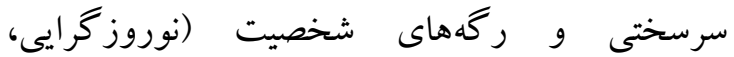

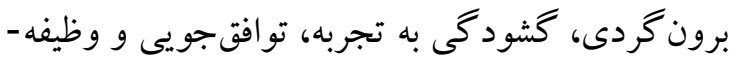
شناسى) آزمون همبستگى بيرسون اجرا شد و نتايج حاصل در جدول 1 نشان داده شده است.

2- Ouellette, S. C.

3- Maddi, S. R., \& Harvey, R. H.

4- Kosca, S. \& Moritaca, L.
انضباطى' 0/81 به دست آوردند. روايى همخراى نمرههاى كل سياهه با ابزارهاى اندازه گيرى درماندگى روانشناختى، عاطفه مثبت و عاطفه منفى، اعتماد به خود، آسيبيذيرى شناختى براى افسردگى، علائم اختلال شخصيت و برسشنامه جُك ليست 90 مادّهاى بررسى شد و همبستكى براى موارد ذكر شده به ترتيب 0/37، 0/34، 0/40- 0/39، 0/35، 0/36 و 0/38 گزارش شد (منجم و ديخران، 1392). در بثزوهش حاضر ضريب آلفاى كرونباخ براى طرحواره سازش نايافته اوليه 0/961 و در حوزه جدايى و طرد 0/909 به دست آمده است.

\section{زمينهياب ديدكاههاى شخصى (PVS؛ مؤسسه}

سرسختى، 1985). يك ابزار خودگزارشدهى 50 مادهاى است كه به ارزيابى سه مؤلفه سرسختى به منزله

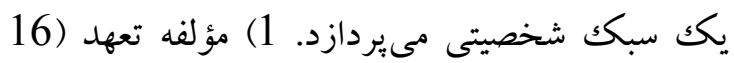
مادّه) گرايش فرد را به درگير شدن با آنجه با آن مواجه مىشود، 2) مؤلفه مهار (17 مادّه) اين باور را كه فرد سازنده رويدادهاى زندگى خويشتن است و ولى مىتواند بر محيط خود تأثير بخذارد و 3. 3) مؤلفه مبارزهجويى (17 مادّه) تمايل به يذيرش تغيير، مواجهه

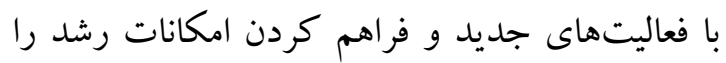
نشان مىدهد. زمينهياب ديد كاههاى شخصى با با ارزيابى اين مؤلفهها، يكك نمره كلّى و سه نمره براى هر يك از مؤلفهها به دست مىدهد (مدى، 1990 نقل از نعمتطاوسى، 1387). اين مقياس از همسانى درونى بالايى برخوردار است. نتايج حاصل از تحليل عاملى اين زمينهياب، سه عامل مرتبط با سازه سرسختى را لران آشكار كردهاند (نعمت طاوسى و محمدعلىشريفى، 1388). روايى و اعتبار اين مقياس كه واجد كار آيى لازم براى گروههاى غير شاغل، كم سواد و عامى است، نسبت به مقياسهاى ديخر بالاتر است (مدى،

1- insufficient self- control / self- discipline 
جدول 1: ضرايب همبستكى سرستىى، ركههاى شخصيت و طرحواره جدايى و طرد

\begin{tabular}{|c|c|c|c|c|c|c|c|c|}
\hline 6 & 5 & 4 & 3 & 2 & 1 & $\underline{\mathrm{SD}}$ & $\underline{\mathrm{M}}$ & متغيرها \\
\hline & & & & & - & $18 / 508$ & $61 / 19$ & 1 - سرسختى \\
\hline & & & & - & $-0 / 416^{* *}$ & $5 / 487$ & $24 / 93$ & 2- نوروز گرايى \\
\hline & & & & $-0 / 287 * *$ & $0 / 300 * *$ & $5 / 779$ & $20 / 44$ & 3- برون گردى \\
\hline & & & $0 / 145 * *$ & $-0 / 071$ & $0 / 212 * *$ & 4/999 & $23 / 49$ & 4- گشود گى به تجربه \\
\hline & & $0 / 241 * *$ & $0 / 597 * *$ & $-0 / 376^{* *}$ & $0 / 338 * *$ & $5 / 510$ & $19 / 92$ & 5- تو افقجويى \\
\hline & $0 / 626$ & $0 / 261 * *$ & $0 / 597 * *$ & $-0 / 346^{* *}$ & $0 / 434 * *$ & $7 / 198$ & $18 / 32$ & 6- وظيفه شناسى \\
\hline$-0 / 382 * *$ & $-0 / 360 * *$ & $-0 / 111 *$ & $-0 / 292 * *$ & $0 / 368 * *$ & $-0 / 318 * *$ & $20 / 947$ & $59 / 42$ & 7-طرحواره جدايى و طرد \\
\hline
\end{tabular}

$* \mathrm{P}<0 / 05 * * \mathrm{P}<0 / 001$

جدايى و طرد و رگهاى شخصيتى برون گردى و r=-0/292) و r r r r $r=-0 / 360$ و (P<0/05)، توافق جويى g r $=-0 / 382$ (P<0/001 نيز رابطه منفى معنادار وجود دارد، اما طرحواره جدايى و طرد با ركه شخصيتى نوروز گرايى (P<0/001 و r=0/368) با توجه به تاييد ارتباط معنادار بين متغيرهاى يزٔوهش (ركههاى شخصيت، سرسختى و طرحواره جدايى و طرد) با يكديخر امكان بررسى نقش واسطهاى لرهي طرحواره جدايى و طرد در ارتباط رگههاى شخصيت

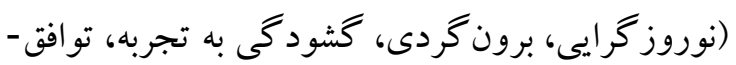
جويى و وظيفهشناسى) و سرسختى فراهم است.
نتايج حاصل از آزمون همبستخى بيرسون در جدول 1 نشان مىدهد بين سرسختى و ركههاى برون گردى إن gr=0/300)

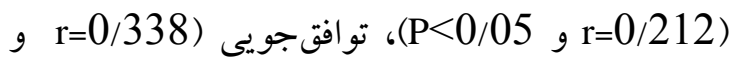

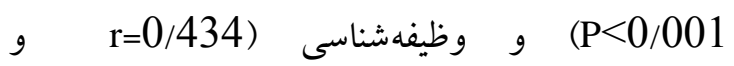
- رابطه مثبت معنادار وجود دارد، درحالى (P<0/001 كه طرحواره جدايى و طرد با رگه شخصيتى

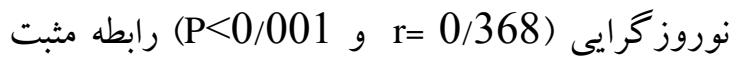

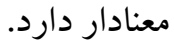

نتايج آزمون همبستخى ييرسون در جدول 1 نشان مىدهد بين سرسختى و طرحواره جدايى و طرد (P<0/001 و r=-0/292) دارد. افزون بر آن اين نتايج نشان مىدهد بين طرحواره 


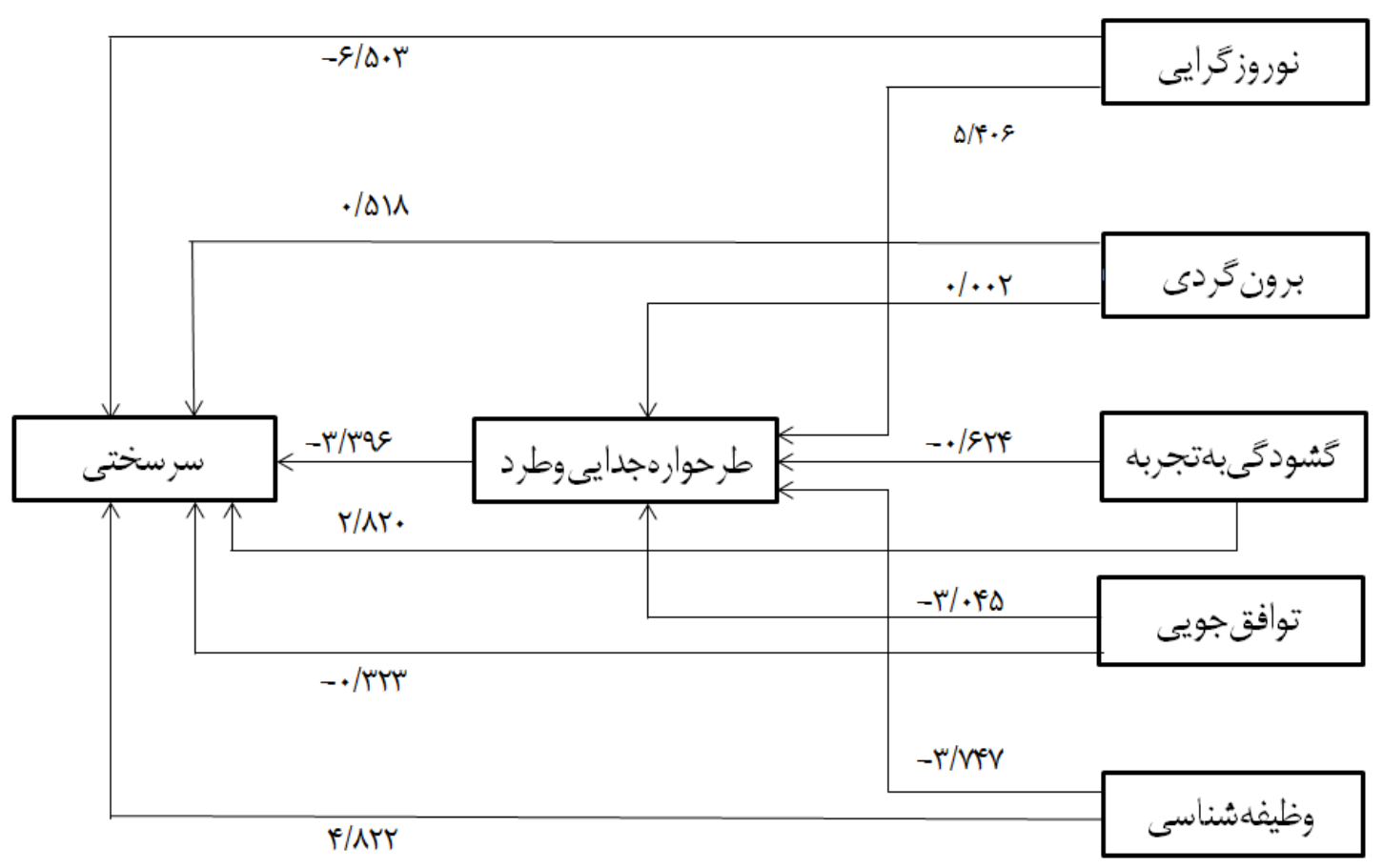

شكل 2: نمودار مسيرهاى برازش يافته با مدل معنادارى

در نتيجه با توجه به شاخصهاى بهدست آمده در

مدل ارائه شده (CFI=0/901 $\left.x^{2} / d f=2 / 435\right)$

‘RMSA=0/063 6 (AGFI=0/921 $6 \mathrm{GFI}=0 / 986$

(NFI=0/906 مدل از برازش مناسب برخوردار است.
به منظور تعيين شاخص هاى براز مدل، يزُوهشكران نسبت خى دو به درجه آزادى كمتر از 3،

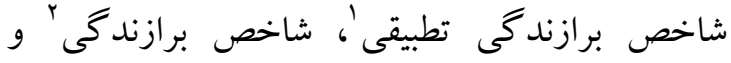

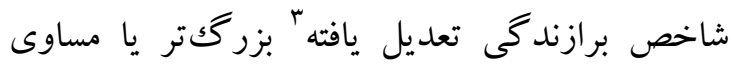
0/90، ريشه دوم واريانس خطاى تقريب 0/08 و شاخص برازندگى غير تطبيقى هزرگكتر از 0/90 را از نشانهاى برازش مناسب و از شاخص هاى مطلوب براى ارزيابى مدل مىدانند. 


\begin{tabular}{|c|c|c|c|c|}
\hline واريانس تبيين شده & اثر غير مستقيم & اثر مستقيم & اثر كل & مسيرها \\
\hline \multirow[t]{6}{*}{$0 / 229$} & & & & بر طرحواره جدايى و طرد از \\
\hline & $0 / 000$ & $0 / 228$ & $0 / 228$ & نوروزرايى \\
\hline & $0 / 000$ & $0 / 000$ & $0 / 000$ & برون گردى \\
\hline & $0 / 000$ & $-0 / 025$ & $-0 / 025$ & كشود گى به تجربه \\
\hline & $0 / 000$ & $-0 / 166$ & $-0 / 166$ & توافق جو يى \\
\hline & $0 / 000$ & $-0 / 203$ & $-0 / 203$ & وظيفه شناسى \\
\hline \multirow[t]{7}{*}{$0 / 297$} & & & & بر سرستى از \\
\hline & $-0 / 032 *$ & $-0 / 269$ & $-0 / 301$ & نوروز گرايى \\
\hline & $0 / 000$ & $0 / 025$ & $0 / 025$ & برون گردى \\
\hline & $0 / 004$ & $0 / 108$ & $0 / 112$ & گشود گى به تجربه \\
\hline & $0 / 024^{*}$ & $-0 / 017$ & $0 / 007$ & توافق جويى \\
\hline & $0 / 029^{*}$ & $0 / 252$ & $0 / 281$ & وظيفه شناسى \\
\hline & $0 / 000$ & $-0 / 142$ & $-0 / 142$ & طرحواره جدايى و طرد \\
\hline
\end{tabular}

$* \mathrm{P}<0 / 01$

جدايى و طرد اثرى معنادار نيست. اين يافتها نشان

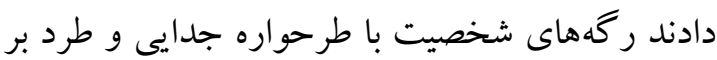
سرسختى اثر غير مستقيم دارد. نتايج جدول 2 بيانكر آن است كه 23 درصد از واريانس طرحواره جدايى و طرد از طريق رگههاى

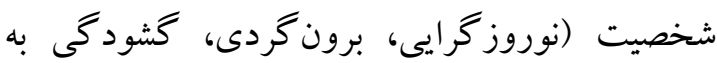
تجربه، توافقجويى و وظيفهشناسى) تبيين بذير است.

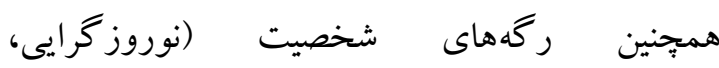
برون گردى، گشود گى به تجربه، توافق جويى و وظيفه شناسى) و طرحواره جدايى و طرد توانيى تبيين 30 درصد از واريانس سرسختى را دارند. اين يافتهها نشان داد طرحواره طرد و جدايى در رابطه با رگههاى شخصيت و سر سختى نقش واسطهاى دارد.

\section{بحث و نتيجه كيرى}

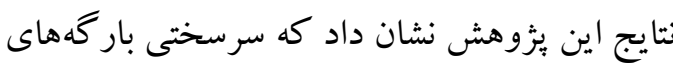

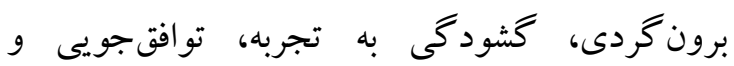

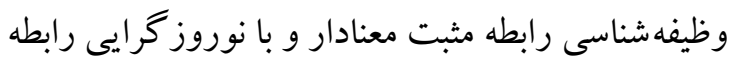

بر اساس مسيرهاى آزمون شده در مدل و نتايج جدول 2 مشاهده مىشود اثر مستقيم نوروز گرايى

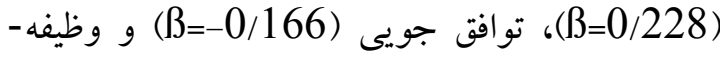
شناسى (

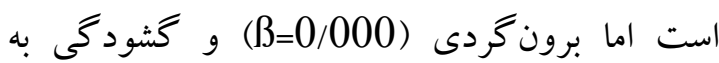
تجربه ( ( ) معنادار نيست. افزون برآن اثر مستقيم نوروز گرايى

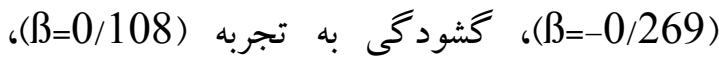
وظيفهشناسى ( (ß/281) و طرحواره جدايى و طرد - بر سرستى نيز معنادار است درحالى (ß)=-0/142) كه اثر مستقيم برون گردى ( ( بر سرستى معنادار نيست.

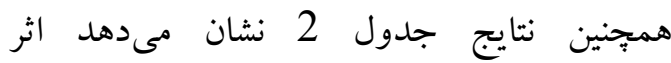

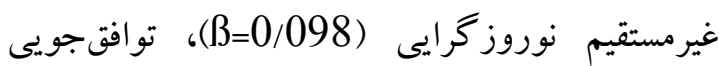
( ) با واسطه طرحواره جدايى و طرد معنادار است اما اثر

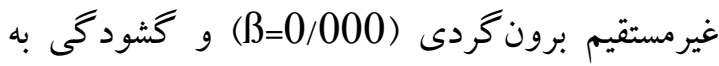
تجربه (م=0/004) بر سرسختى با واسطه طرحواره 
آيند (مبشرى و كافى، 1395). در بُزوهشهاى ديخر

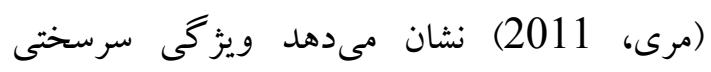

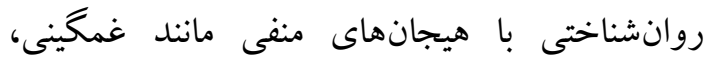

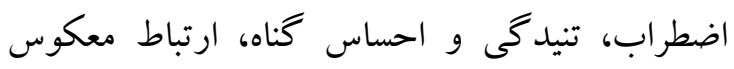
دارد. طبق اين يثزوهشها، افرادى كه از وئز احسى سرسختى كمترى برخوردارند، هيجانهاى منفى را لـ تجربه مى كنند. در ارتباط با رابطه منفى سرسختى با طرحواره طرد و جدايى نيز اين يافته با بزوهشهاى بيشين در اين زمينه همسو بود (آنتونسكى، 1979؛ ينلى و توماكو،

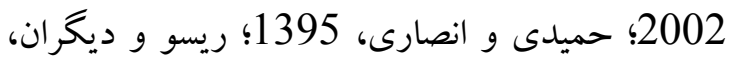
2007؛ غفارى، 1391؛ نورى قلعهليخانى و حافظى، 1395؛ فيجرمتيو، اسموا بِاوول و دلفابرو، 2016؛ ورنر، 1997؛ يانگك، 1389؛ يوسفى، 1393 و يوسفى و ديخران، 1394 و مدى، 2013). در تبيين اين نتايج مىتوان كفت طرحواره طرد وجدايى اغلب به صورت احساس بوجى و سردر گمى، جهت نداشتن

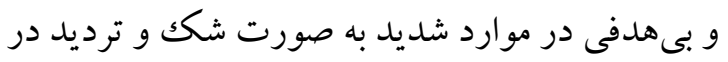
موجوديت و ساختار وجودى فرد بروز مى كند طرحوارهها در برخى از فرايندهاى ذهنى ممكن است در نقش عاملى مقاوم در برابر تغيير عمل كنند. طرحوارهها مركب از باورها و مفروضاتى در مورد خطر و ناتوانى در مقابله با آنها هستند (ريسو و و ديخران، 2007). از آنجايى كه روبرو شدن با وقايع

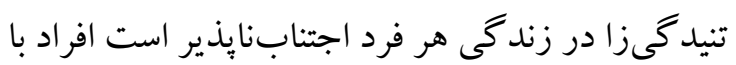
طرحواره طرد وجدايى توانايى كمترى براى مقابله با اين موقعيتها داشته و سرسختى بايينترى نشان مى دهند. همجنين افرادى كه در حوزه طرد وجدايى قرار دارند به درستى و صداقت ديخران اعتمادى ندارند (يانگك، 1389) اين افراد هيجانهاى منفى شديدى مثل شرم، ترس، خشم و بىاعتمادى را تجربه مى كنند و ديدى بديينانه به افراد و محيط بيرونى دارند (يوسفى وبى
منفى معنادار دارد. اين نتايج با بثزوهشهاى ديخر در قلمرو ركهاى شخصيتى و سرسختى همخوان است (احمدى و ديخران، 1394؛ اسكومورووسكى و و سادوم، 20011؛ تئيدور و ديخران، 2015؛ دولبير و ونمرون ديخران، 2007؛ زانكك، 2011؛ فولادى و ديخران،

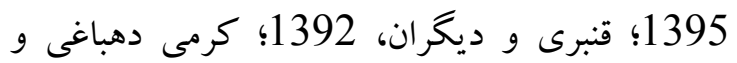
احمديان، 1396؛ كوباسا، 1982؛ مبشرى و وكافى، 1395؛ مرى، 2011؛ مستغنى و سروقد، 1391؛ مكك كان و ديخران، 2009 ). در تبين اين نتايج مىتوان كفت ساختار شخصيت بر سرسختى تأثير مى كذارد. افرادى كه داراى مقاومت بالا هستند، سرسختى بيشترى نشان مىدهند (تئيدور و ديخران،

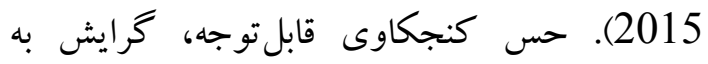
تجارب جالب و معنادار، اعتقاد به اثر آنجه به طور

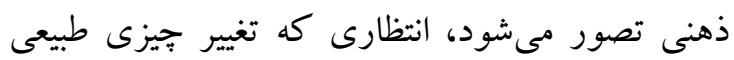

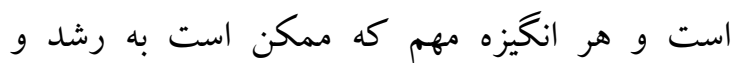
بيشرفت منجر شود، خودرأيى و قدرت، توانايى استقامت و مقاومت، ممكن است در ساز گارى با وقايع دشوار زندگى مفيد باشد. يزوهشها نشان مهان ميدهد كه سرسختى مؤلفهاى است كه تمايل به داشتن تجارب جديد، ابراز وجود، يرانرزى بودن، توانايى، بِافشارى و و پايدارى بيشتر مشخصشده است (كوباسا، 1982). شاخص توافقجويى، بر كرايشهاى ارتباط بين فردى

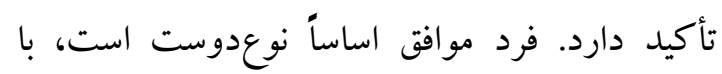
ديخران احساس همدردى مى كند و مشتاق كمكك به آنان است (كرمىدهباغى و احمديان، 1396). همجنين از ركههاى شخصيتى مؤلفه وظيفهشناسى توانسته است سرسختى روانشناختى را بيشبينى كند

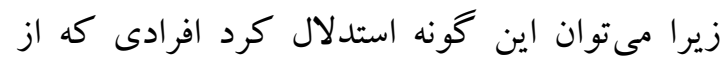
وظيفهشناسى بيشترى برخوردارند نسبت به افرادى كه

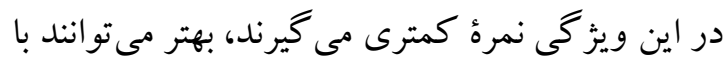
فشارها و مشكلات ناشى از شغل و زندكى خئ خود كنار 
است و با برون گردى، گشود گى به تجربه، توافقجويى و وظيفهشناسى منفى و معنادار دارد. يُزوهش حاضر با نتايج بيزوهشهاى قبلى هماهنگك است (امانى و و ديخران، 1394؛ بهر امىزاده و بهر امى احسان، 1392؛

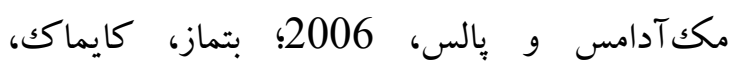
كو كبيك و تار كايار، 2014؛ بنبن و ديخران، 2017؛ بوسمانس و ديخران، 2010؛ تيم، 2010؛ جينز،

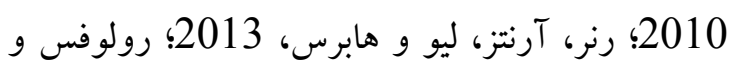
ديخران، 2016؛ ريسكيند، كليمان، 2012؛ ساوا، 2009؛ فلينك و ديخران، 2017؛ كالويت، 2014؛ كارتر و ديخران، 2013؛ لهى، 2012؛ مالو گيانيز و

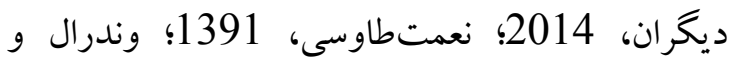
ديخران، 2016 و هالوورسن و ديخران، 2009). در تبيين اين نتايج مىتوان كفت شرايط محيطى اوايل زندكى به ويز گى هاى شخصيتى در بزر گت سالى مرتبط است (بنبن و ديخران، 2017). تيم (2010)، فلينك ونك و ديگران (2017)، كالويت (2014) اعتقاد دارند طر حوارههاى سازش نايافته اوليه با ابعاد شخصيتى رابطه دارد و بنابراين امكان يكهيارجه كردن و تركيب آنها نيز وجود دارد. به نظر كالويت (2013) و هالوورسن و

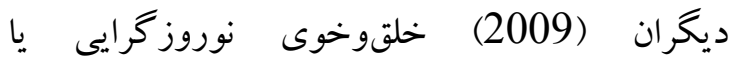
عاطفهيذيرى منفى يك عامل آسيبذيذيرى كلى يا خلقوخوى آسيبذيذير است كه مىتواند منجر به شكل گيرى طرحواره شود. در ارتباط با رابطه منفى إنى برون گردى با طرحواره طرد و جدايى مى توان كفت كه برونگردى به فعاليتها، هيجانهاى مثبت، تجارب

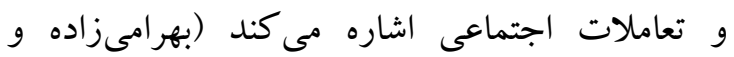
بهرامى احسان، 1392). در صورتى كه اين حوزه از

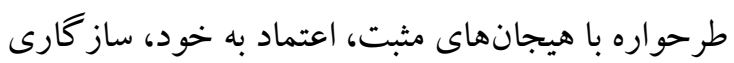
و تعاملات اجتماعى رابطه منفى دارند. همجنين رابطه

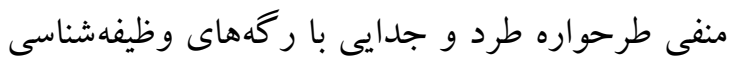
و توافق جويى را مىتوان اينكونه تبيين كرد كه
و ديخران، 1394). همجينين اين افراد احساس مى كنند

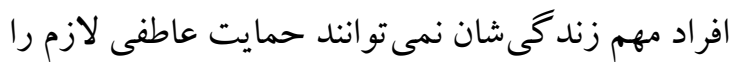
به او بدهند در نتيجه جنين افرادى از سرسختى بايينى

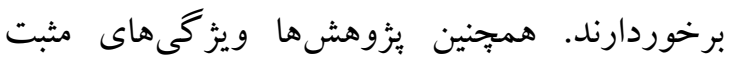
خانوادگى همانند همبستخى، حمايت عاطفى اعضاء از همديخر و با ساختار بودن را در مقاوم ساختن افراد همادي براى مقابله با فشارهاى زندگى نشان دادهاند (ورنر،

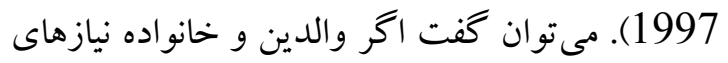

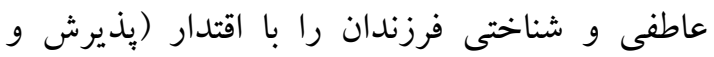
محدوديت با احترام) بر آورده كنند آنان دنياى بيرامون خود را با ارزش مىبيند و حس تعهد در آنها شكل

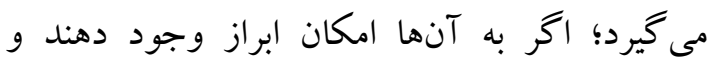
فرزندان احساس كنند كه در حل مسائل قابليت و شايستگى كافى و بر محيط خود تسلط كافى دارند، حس كنترل در آنها به وجود مى آيد و در نهايت وقتى والدين به فرزندان بياموزند كه تجربههاى متنوع

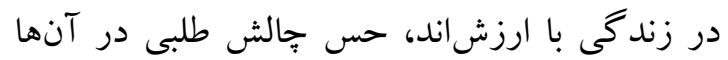
بروز مى كند (مدى، 2013 و حميدى و و انصارى،

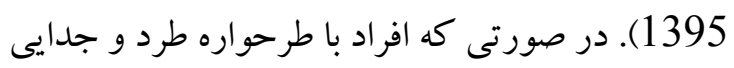
تمايلات و نيازهاى فرد به حمايت عاطفى به اندازه كافى از جانب ديخران ارضاء نمىشود، فقدان توجه، دركك نشدن و به حرف دل فرد كوش ندادن و كلا محروميت هيجانى از خصيصههاى بارز اين افراد است در نتيجه اين افراد در سرسختى نمره يايينى مى كيرند

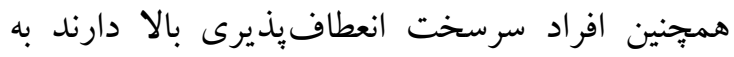
جاى اتكا بر جنبههاى ثابت زندگى بر انجام تغييرات و و

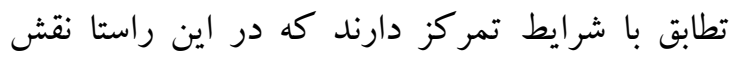
طرحوارهها با انعطاف يذيرى و نقش خانو اده و والدين در اين امر بسيار حائز اهميت است (فيجرمتيو، اسموا

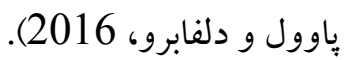
نتايج اين يُزوهش نشان داد رابطه طرحوارههاى حوزه جدايى و طرد با نوروز گرايى مثبت و معنادار 
طورى كه احساساتى مانند ترس، غم و برانگيختخى

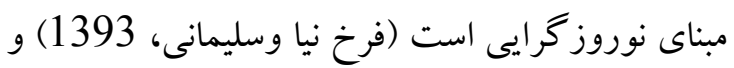
ميانگين نمرههاى طرحواره سازش نايافته اوليه در اين

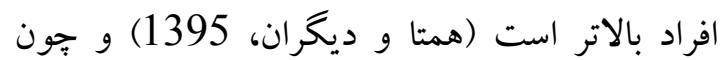
داشتن اين احساسات منفى اثرات مخربى بر ساز گارى فرد دارد، بالابودن نمرءٔ افراد در اين عامل نشاندهندهُ وضعيت انطباقى ضعيف (كاستا و مكى كرى، 1992) و در نتيجه سرسختى بايين فرد است. رضايى و ديخران (1392) نيز نشان دادند طرحواره طرد و جدايى به طور معنادارى با عامل نوروز گرايى همبستخى مثبت دارند.

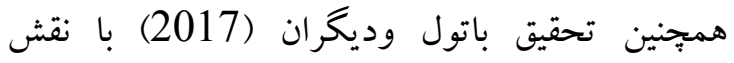

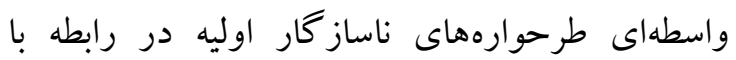
اختلالات تبين كننده اين فرضيه است؛ و در رابطه با وظيفهشناسى و توافقجويى، افر اد وظيفهشناس افرادى با كفايت و منظم و ركههاى توافق جويى شامل اعتماد و نوعدوستى مىباشد كه اين دو عامل با طرحواره طرد وجدايى رابطه منفى دارند زيرا افراد با طرحو اره طرد و جدايى ديد بدبينانه و بىاعتمادى، كمرويى، احساس ناامنى و عدم مسئوليت به خاطر ترس از تحقير شدن و كنارهگيرى از افراد را دارند (رضايى و ديخران، 1392) ايجاد اين طرحواره نيز باعث بايين آمدن سرسختى مىشود زيرا افراد سرسخت نسبت به نتايج كارهاى خويش، احساس مسئوليت بيشترى مى كند و ديد مثبت و خوشبينانه به ديخران و زندكى دارد (مهرابى و ديخران، 1394). در اين بيزوهش وظيفهشناسى با نمره كل سرسختى روانشناختى و مؤلفههاى آن رابطه معنادار دارد، يعنى اكر فرد از

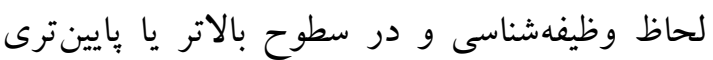
باشد، سرسختى روانشناختى او نيز به همان اندازه افزايش يا كاهش مىيابد. در آخر از يافتهاى به دست

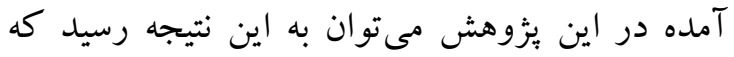

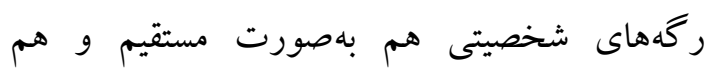

طرحوارههاى اين حوزه به طور معمول در خانو ادههايى

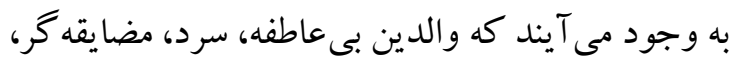
منزوى، تندخو و غير قابل بيشبينى هستند و در اين شرايط نيازهاى فرد به امنيت، ثبات، همدلى، محبت، در ميان گذاشتن احساسات، يذيرش و احترام به شيوه قابل

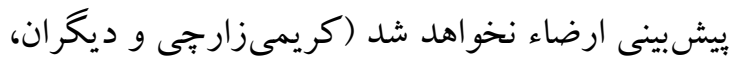
1392) در حالى كه بخشش، مهربانى و همدلى از ويز گىهاى توافقجويى و در و وظيفهشناسى افراد هدفمند، قابل اعتماد، منضبط، با اراده و مصمم هستند. ويزگى مشترك توافق جويى و وظيفهشناسى آن است

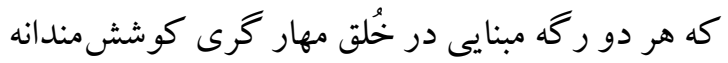
دارند (نعمت طاوسى، 1391). همجينين طرحوارهها يكك عامل بسيار قدرتمند در تبيين اختلالات هيجانى هستند، طورى كه نقش آنها در اختلالات روانى مختلف بهويزه افسردگى و نوروز گرايى مورد تائيد قرارگرفته است (لهى، 2012 و بتماز و ديخران، وردئ .(2014

با توجه به يافتهاى اين بزوهش، طرحواره جدايى

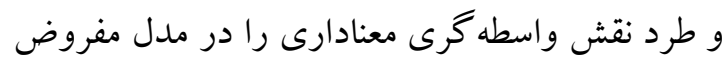
ما نشان دادند. نتايج اين يزوهش با تحقيق امانى و ديخران 1394؛ باتول، شيهزادى و رياض، 2017؛ رضايى و ديخران، 1392؛ زارجى و ديخران، 1392؛

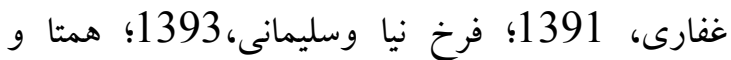
ديخران، 1395 و يوسفى، 1393 همسو است. بر اساس نتايج آزمون تحليل مسير در مدل ارائه شده اين يزوهش، طرحواره جدايى و طرد فقط در

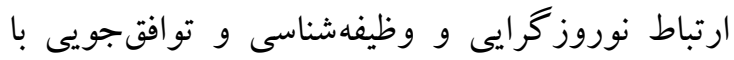
سرسختى نقش واسطهاى دارد و اين اثر غير مستقيم و معنادار است. يكك تبيين احتمالى در ارتباط با نقش واسطهاى طرحواره طرد و جدايى در رابطه بين نوروز گرايى و سرسختى آن است كه عامل نوروز كرايى در واقع شاخص بىثباتى هيجانى است. به 
موردبررسى قرار گيرد يك نمونه بزرگكتر به ما كمك مى كند تا به بررسى و تحليل هاى جزيىتر مثل رابطه بين طرحوارههاى خاص ديخر نيز ببردازيم همجينين بيشنهاد مى شود اين تحليل ها در رابطه با طبقات خاص اختلالات شخصيت يرداخته شود. نتايج اين يزوهش مى تواند راهنماى خوبى براى جلسات درمان و يا اتخاذ

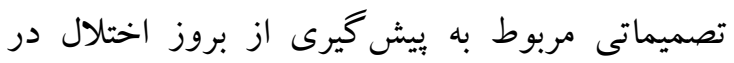

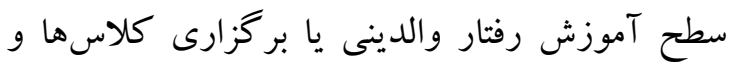

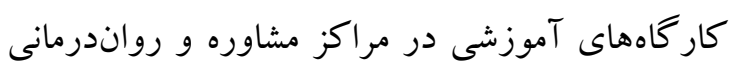
با هدف بهبود عملكرد خانو ادهها باشد. به دليل نقش طرحوارهها در زندگى و تأثير همه - هـ

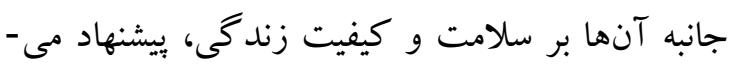

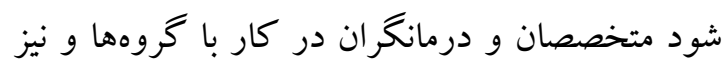
تدوين برنامههاى درمانى رويكرد طرحواره درمانى را مورد توجه قرار دهند.

\section{References}

Ahmadi, F., Naeinian,M. R \& Hydarinasab, L. (2015). To Study Simple and Multiple Correlation among Extroversion and Psychological Hardiness with Happiness in Students Regarding to Sexuality. Journal of Clinical Psychology, 6(4), 63 -74 (Persian).

Alexander, D. A. \& Klein, S. (2001). Ambulance personnel and critical incidents. British Journal of Psychiatry, 178, 76-81.

Amani, A., essa Nezhad, A. \& azizi, A. (2016). Structural Relationships of Early Maladaptive Schemes and Personality Factors with Marital Adaptation. Quarterly Journal of Advanced Psychological Research, 10 (37), 70-45 (Persian).

Antonovsky, A. (1979). Health, stress, and coping: new perspective on mental and physical well-being. San Francisco: Jessey Bass.

$$
\begin{aligned}
& \text { غيرمستقيم به واسطه متغير طرحواره جدايى و طرد } \\
& \text { مى توانند سرسختى را بيشبينى كند. } \\
& \text { انجام يزٔوهش حاضر تنها در گستره دانشجويان } \\
& \text { دانشگاه ييام نور استان قم بود كه تعميميذيرى آن رابا } \\
& \text { دشوارى مواجه مىسازد و نيز لحاظ نشدن متغيرهاى } \\
& \text { اقتصادى، اجتماعى نمونه مورد مطالعه، از محدوديت- } \\
& \text { هاى اين يُوهش تلقى مى إنود. }
\end{aligned}
$$

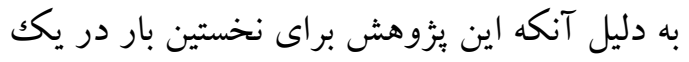

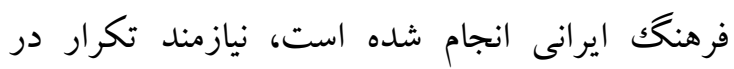

$$
\begin{aligned}
& \text { نمونهاى مختلف و تأيدهاى تجربى بيشتر است؛ } \\
& \text { بنابراين، يافتهاى يُزوهشى بايد با احتياط تفسير شوند. }
\end{aligned}
$$

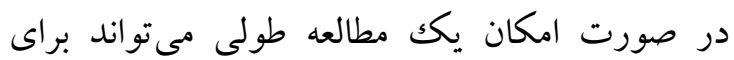

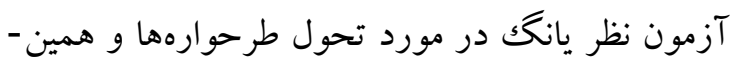

$$
\begin{aligned}
& \text { طور شكل گيرى اختلالات شخصيت مناسب باشد. بهتر } \\
& \text { است از يرسشنامهاى اجتناب، جبران و و تسليم } \\
& \text { طرحوارهاى يانگك نيز در كنار برسشنامه طرحواره } \\
& \text { يانگك استفاده شود تا نقش اين سبك هاى مقابلهاى نيز }
\end{aligned}
$$

Ayyoubi, S., Timurid, S. \& Nairi, M. (2010). Tenacity, quality of life and a sense of well-being. Journal of Developmental Psychology, 6 (24), 360353 (Persian).

Bahramizadeh, h. \& Bahrami Ehsan, e. (2013). Internal relations of early maladaptive schemas and personality traits. Journal of Research in Behavioral Sciences, 11 (3), 227-219 (Persian).

Batmaz, S., Kaymak, S. U., Kocbiyik, S. \& Turkcapar, M. H. (2014). Metacognitions and emotional schemas: a new cognitive perspective for the distinction between unipolar and bipolar depression. Comprehensive Psychiatry, 55(7), 1546-55.

Batool, N, Shehzadi, H, Riaz, M.N. \& Riaz, M. A. (2017). paternal malparenting and offspring personality disorders: Mediating effect of early maladaptive schemas. Journal of the Pakistan Medical Association, 67(4), 556-560. 
Bin-Bin, C., Zeyi, S. \& Shijin, S. (2017). Life history strategy as a mediator between childhood environmental unpredictability and adulthood personality. Personality and Individual Differences, 111(1), 215-219.

Bosmans, G., Braet, C., \& Van V. L. (2010). Attachment and symptoms of psychopathology: early maladaptive schemas as a cognitive link? Clinical Psychology Psychothery, 17(5), 374-85.

Calvete, E. (2014). Emotional abuse as a predictor of early maladaptive schemas in adolescents: Contributions to the development of depressive and social anxiety symptoms. Child Abuse \& Neglect, 38 (4), 735-746.

Calvete, E., Orue, L. \& Hankin, B. L. (2013). Early maladaptive schemas and social anxiety in adolescents: The mediating role of anxious automatic thoughts. Journal of Anxiety Disorders, 27, 278-288.

Carter, J. D., McIntosh, V.V., Jordan, J., Porter, R. J., Frampton, C. M., \& Joyce, P. R. (2013). Psychotherapy for depression: A randomized clinical trial comparing schema therapy and cognitive behavior therapy. Journal of Affective Disorders, 151(2), 500-05.

Claridge, G., Davis, C. (2001). What's the use of neuroticism? Personality and Individual Differences, 31(3), 383- 400.

Costa, P. T., \& McCrea, R. R. (1985).The NEO personality inventory manual. Odessa, FL: Psychological Assessment Resources.

Delahaij, R.G, Anthony, W.K, \& van Dam, K. (2010). Hardiness and the response to stressful situations: Investigating mediating processes. Personality and Individual Differences, 49, 386-390.

Dolbier, C. L., Smith, S. H., \& Steinhard, M. A. (2007). Relationships of protective factors to stress and symptoms of illness. American Journal of Health Behavior, 31(4), 423-433.
Farkhnia, A. \& Soleimani, M. (2014). The role of personality traits and maladaptive schemas in predicting the health of students (girls and boys). Journal of Disability Studies, 4 (4), 42-33 (Persian).

Farshi, m. T, Mehryar, A. E. \& Tabatabai, M. (2001). Application of the new Neo character test and analysis of its characteristics and its factor structure among Iranian university students. Quarterly journal of human sciences, Alzahra University (Q), 11 (39), 198-173 (Persian).

Fischer, D., Matthew, F., Smout Paul, F. \& Delfabbro, H. (2016). The relationship between psychological flexibility, early maladaptive schemas, perceived parenting and psychopathology, Journal of Contextual Behavioral Science, 5(3), 169-177.

Flink, N., Lehto, S. M., KoivumaaHonkanen, H., Viinamäki, H. Ruusunen, A., Valkonen- M. \& Korhonen, H. K. (2017). Early maladaptive schemas and suicidal ideation in depressed patients. The European Journal of Psychiatry, 31(3), 8792.

Foladi, N. \& Shahidi, A. (2016). The role of personality traits and life expectancy in the prediction of psychological hardiness among students according to gender. Clinical psychology and personality-Daneshvar, former behavior (Persian).

Ghaffari, F. (2012). Intermediate role of early maladaptive schemas in relation to students' attachment styles and psychological hardiness. Master's Degree, Faculty of Educational Sciences and Psychology, Islamic Azad University, Marvdasht Branch (Persian).

Ghanbari, V., Shakib, V., Ghanbari, A., Rahimi, S. \& Baghani, R. A. (2013). The Effect of Hardship Training on Students' Compatibility and Accountability in Police University. Journal of Research in Educational Sciences, 1 (1), 98-83 (Persian). 
Grossi Foroshi, M. (1998). Standardization of NEO personality test and analysis and analysis of its characteristics and its structure among Iranian university students. $\mathrm{PhD}$ thesis, Faculty of Humanities, Tarbiat Modares University (Persian).

Grossi Foroshi, M. (2001). New Approaches to Personality Evaluation (Application of Factor Analysis in Personality Studies). Tabriz: Publication of the Society (Persian).

Haghighi, J., Attari, Y., Rahimi, AS. And Soleimiennia, L. (1999). The relationship between hardiness and its components with health in undergraduate students. Journal of Educational Sciences and Psychology, Shahid Chamran University Ahvaz, 3rd and 4th, 18-1 (Persian).

Halvorsen, M.,Wang, C. E., Richter, J., Myrland, I., Pedersen, S. K., Eisemann, M., \& et al.(2009). Early maladaptive schemas, temperament and character traits in clinically depressed and previously depressed subjects. Clinical Psychology andPsychotherapy, 16, 394-407.

Hamidi, F. \& Ansari, Sh. (2016). The Relationship between Parents 'Parenting Styles and Hard Students' Psychological Well-being. Quarterly Journal of Family and Research. 32, 65-47 (Persian).

Hamta, A., Kazemnejad, A., Fesharaki, M. GH., Fekri N. \& Abol Fattahi, M. (2016). Identification of early maladaptive schemas based on Young's questionnaire in high school girls in Qom. Journal of Qom University of Medical Sciences, 10 (9), 35-4 (Persian).

Jens, C. T. (2010). "Personality and early maladaptive schemas: A five-factor model perspective." Journal of Behavior Therapy and Experimental Psychiatry, 41(4), 373-380.

Karami Dehbaghi, M. \& Ahmadian, S. M (2017). Investigating the Relationship between Personality and Self-efficacy Characteristics with Organizational Commitment in Police Command Officers of Tehran. Scientific publication Trans., 12 (47), 78-63 (Persian).

Karimizarchi, M. Sohrabi, F. \& Shams, C. (2013). Intermediate role of early maladaptive schemas between perceived parenting style and personality traits of cluster B. Journal of Modern Psychological Research, 8 (32), 225-206 (Persian).

Kaymehr, G. (2002). Standardization of the short form of the questionnaire and its factor structure NEO.F.F.I Five factors (confirmatory analysis) among the students of the Faculty of Humanities of the University of Tehran. Master thesis, Allameh Tabatabaei University, Faculty of Psychology and Educational Sciences (Persian).

Kline, R.B. (2010). Principles and practice of structural equation modeling (3rded.). New York: GuilfordPress.

Kobasa, S. C. (1979). Stressful life events, personality, and health: An inquiry into hardiness. Journal of Personality and Social Psychology, 37(1), 1-11.

Kobasa, S.C., \& Puccetti, M. C. (1983). Personality and social resources in stress resistance. Journal of Personality and Social Psychology, 45, 50-839.

Kobasa, S.C., Maddi, S.R., \& Kahn, S. (1982). Hardiness and health: A prospective study. Journal of Personality and Social Psychology, 42(1), 168-177.

Lambert, V. A. (2007). Predictors of Physical and mental health in hospital nurses within people's Republic of China. International Nursing Review, 54(1), 8591.

Leahy, R. L. (2012). Emotional Schema Therapy: A Bridge Over Troubled Waters. In: Herbert JD, Forman EM, editors. Acceptance and mindfulness in cognitive behavior therapy: understanding and applying the York: John Wiley \& Sons, P. 154.

Lotfi, N. \& Saadati Shamir, A. (2016). Investigating the Relationship between Personality Characteristics and Attachment Styles with Student's Emotional Breakdown in Clinical Psychology 
Research and Consultation, 6 (1), 98-112 (Persian).

Lovering, M. E., Heaton, K. J., Banderet, L. E., Neises, K., Andrews, J. \& Cohen, B. S. (2015). Psychological and physical characteristics of U.S. Marine recruits. Military Psychology, 27(5): 261275.

MacCann, C., Duckworth, A. L,. \& Roberts, R. D. (2009). Empirical identification of the major facets of conscientiousness. Learning and Individual Differences, 19, 451- 458.

MacCann, C., Duckworth, A. L,. \& Roberts, R. D. (2009). Empirical identification of the major facets of conscientiousness. Learning and Individual Differences, 19, 451- 458.

Maddi, S. R., \& Harvey, R. H. (2006). Hardiness considered across cultures. In P. T. P. Wong \& L. C. G. Wong (Eds.), Handbook of multicultural perspectives on stress and coping. New York: Springer.

Maddi, S.R. (2013). Hardiness: Turning stressful circumstances into resilient growth (pp. 29-41). Springer.

Mahbod, M. \& Folad Chang, m. (2016). The Relationship Between Five Great Factors of Personality and Unproductive Educational Behavior with Intermediate Perceived Inhibition: Structural Modeling. Quarterly journal of psychology: Iranian psychologists. (47), 279-265(Persian).

Malogiannis, I. A., Arntz, A., Spyropoulou, A., Tsartsara, E., Aggeli, A, \& Karveli, S., et al. (2014). Schema therapy for patients with chronic depression: A single case series study. Journal of Behavior Therapy and Experimental Psychiatry,45(3), 319-29.

Mc Crae, R. R., \& Costa, P.T. (1985). Comparison of EPI and psychoticism scales with measures of the five-factor model of personality. Personality and Individual Differences, 6, 587-597.

McAdams, D. P., \& Pals, J. L. (2006). A new big five: fundamental principles for an integrative science of personality. American Psychologist, 61, 204-217.
Mehrabi, H., A. Mirzaei, Gh. Fathi Eshtiani, A. \& Karaminia, R. (2015). The role of personality traits in the life style of the military. Quarterly journal of military psychology, 6 (21), 38-29 (Persian).

Mobasheri, M. \& Cafi, S. M. (2016). The Relationship between Personality Characteristics and Psychological Hardiness of Operative Room Operators in Al-Zahra Hospital in Isfahan in 2014. Razi Journal of Medical Sciences, 23 (143), 4756 (Persian).

Monajem, A., Agha Yossefi, A. R. \& zare, H. (2013). Comparing the domains of maladaptive schemas and the style of parenting and life traps of divorced, normal women. Journal of Behavioral Sciences, 7 (3), 142-133 (Persian).

Mostaghna, S \& Sarvqd, S. (2012). Relationship between personality traits and psychological hardiness with job stress in nurses of Shiraz Hospital. Journal of Psychology and Practice, 13 (4), 124-32 (Persian).

Muris, P. (2006). Maladaptive schemas in non-clinical adolescents: Relations to perceived parental rearing behaviours, big five personality factors and psychopathological symptoms. Clinical Psychology and Psychotherapy, 13, 405413.

Murray, R. A. (2011). Interpersonal guilt and self- defeating behavior of foster youth. Social and Behavioral Sciences, 30.

Murray, R. A. (2011). Interpersonal guilt and self- defeating behavior of foster youth. Social and Behavioral Sciences, 30.

Nemat Tavosi, M. \& Mohammad Ali Sharifi, M. (2009). Hardiness as a source of support at work: a predictor variable for professional stressors. Quarterly Journal of Psychological Research, 4, 62- 49 (Persian).

Nemat Tavosi, M. (2008). The Effect of Gradual Deterioration Training on Managing Stresses Caused by Everyday Events. Quarterly journal of Iranian psychologists, 4 (16), 332-321 (Persian). 
Nemat Tavosi, M. (2012). Personality and Coping (Part I). Evolutionary Psychology: Iranian Psychologists 8 (32), 416-414 (Persian).

Nouri Ghale Ali Khani, F. \& Hafezi, F (2016). Relationship between psychological hardiness and substance abuse in students of Islamic Azad University, Ahwaz. Second International Conference on Applied Research in Educational Sciences and Behavioral Studies and Social Violations of Iran (Persian).

Orue, I., Calvete, E. \&. Padilla, P. (2014). Brooding rumination as a mediator in the relation between early maladaptive schemas and symptoms of depression and social anxiety in adolescents. Journal of Adolescent Health,3(8), 91- 1281.

Penley, J. A., \& Tomaka, J. (2002). Associations among the Big Five, emotional responses, and coping with acute stress. Personality and individual differences, 32(7), 1215-1228.

Quirk, S. E. (2015). Personality Disorder and Population Mental Health. The Lancet Psychiatry, 2(3), 201-212.

Renner, F., Arntz, A., Leeuw, I.\& Huibers, M. (2013). Treatment for Chronic Depression Using Schema Therapy. Clinical Psychology: Science and Practice - Wiley Online Library,20(2), 166-80.

Rezaei, M., Gholam Razaei, S., Sehvandi, M. A., Ghazanfari, F. \& Derrickde, f. (2013). The power of early maladaptive schemas and personality dimensions in predicting depression. Magazine of Thought and Behavior, 8 (29), 88-77 (Persian).

Riskind, J. H., \& Kleiman, E. M. (2012). Looming cognitive style, emotion schemas, and fears of loss of emotional control: Two studies. International Journal of Cognitive Therapy, 5(4), 392-405.

Riso, L. P., Maddux, R. E., \& Santorelli, N. T. (2007). Early maladaptive schemas in chronic depression. In L. P. Riso, P. L. du Toit, D. J. Stein \& J. E. Young (Eds.), Cognitive schemas and core beliefs in psychological problems. A scientist practitioner guide (pp. 41e58). Washington, DC: American Psychological Association.

Roelofs, J., Muris, P., Wesemael, D. V., Broers, N. J., Shaw, I. \& Farrell, J. (2016). Group-Schematherapy for Adolescents: Results from a Naturalistic Multiple Case Study. Journal of Child and Family Studies, 25 (7), 2246 -2257.

Sanchez, F., \& Martnez, H. (2015). The relationship between hardiness and social development between male and female students. Aula Orientalis, 1,216-23.

Sava, F. A. (2009). Maladaptive schemas, irrational beliefs, and their relationship with the five- factor personality model. Journal of Cognitive and Behavioral Psychotherapies, 9, 135147.

Sheard, M., \& Golby, J. (2007). Hardiness and undergraduate academic study: The moderating role of commitment. Pers Indiv Differ. 43, (3), 579-88.

Skomorovsky, A. \& Sudom, K .A. (2011). Psychological well-being of Canadian Forces officer candidates: The unique roles of hardiness and personality. Military medicine, 176(4), 389-96.

Tarimoradi, A. (2014). Comparing the degree of hardiness and public health between Iranian and English Women University students. Procedia - Social and Behavioral Sciences, 116, 101-105.

Teimuri, S. \& Mashhadi, A. (2008). Hardiness and Personality Characteristics of Acquired Students. Journal of Psychological Sciences, 25, 114-102 (Persian).

Tejedor, E., Pedro, M. Beltrán, B., Boada-Grau, J., \& Lucas-Mangas, S. (2015). Hardiness as a moderator variable between the Big-Five Model and work effort. Journal Personality and Individual Differences, 85, 105-110.

Thimm, J. C. (2010). Personality and early maladaptive schemas: A five factor model perspective. Journal of Behavior Therapy and Experimental Psychiatry, 41, 373-380. 
Thimm, J. C. (2010). Relationships between early maladaptive schemas and psychosocial developmental task resolution. Clinical Psychology \& Psychotherapy، 17(3), 219-30.

Tibaret, D. H. (2011). Developing concepts of musical style. Musicaescientiae, 3, 193-216.

VanderWal, R.A.1., Bucx, M. J., Hendriks, J.C., Scheffer, G.J, \& Prins, J. B. (2016). Work stress and satisfaction in relation to personality profiles in a sample of Dutch anaesthesiologists: A questionnaire survey. Journal Anaesthesiol, 33(11), 800-806.

Werner, E. E. (1997). Vulnerable but invincible: high risk childrenFrom adulthood. Acta Paediatica Supplement, 422, 103-105. .

Yang, J., Colosseau, J., Vishar, M. (2010). Therapeutic Therapy (A Practical Guide for Experts). Translate h Hamidpur And $\mathrm{z}$ Endose Tehran: Arjmand Publications (Persian).

Young, J. E., \& Brown G. (1994). Young schema questionnaire: A schemafocused approach. Journal Cognitive Therapy Personality Disorder, 63-76.

Young, J. E., Klosko, J. S., \& Weishaar, M. E. (2003). Schema therapy:
A practitioner's Guide. New York: Guilford Press.

Yousefi, N., Etemadi, A., Bahrami, F., Ahmadi, A., Bashlida, K. \& Fatehizadeh, M. (2008). Psychometric Indexes of Early Maladaptive Schemes (EMSs). Ph.D. thesis of family counseling. Faculty of Sciences and Psychology, University of Isfahan (Persian).

Yousefi, R., Chelbyanlou, Gh. R. \& Baghban Novin., R. (2015). Prognosis of personality disorder symptoms based on early maladaptive schemas and personality traits. Journal of Behavioral Sciences, 9 (1), 50-41 (Persian).

Yousefi, S. (2014). Relationship between early maladaptive schemas and explanatory style (optimism-pessimism) with psychological hardiness. Master's thesis, Faculty of Psychology and Educational Sciences, Islamic Azad University, Tehran Central Branch (Persian).

Zakin, G., Zahava, S., \& Yuval, N. (2003). Hardiness, attachment style, and long term psychological distress among Israeli POWs and combat veterans, Personal and Individ Differ,34, 819-829.

Zhang, L. F. (2011). Hardiness and the Big Five personality traits among chines university students. Learniue and Individul Differences, 21(1), 109-113. 